\title{
Economic Security Formation of Enterprise Under the Conditions of Steady Development
}

\author{
By Oksana Hryvkivska ${ }^{1}$, Nataliia Kotvytska ${ }^{2}$, Natalia Ivanova ${ }^{3}$, Nataliia Pryimak ${ }^{4}$, \\ Iryna Salkova ${ }^{5}$
}

\begin{abstract}
The most relevant aspects of achieving economic security of enterprises are determined in the article. The assessment of the level of economic security was conducted using the method of analysis of the functioning environment. The focal points of the assessment are interests, threats and resources. The possibility of economic security strengthening of business entities is traced using analysis of economic activity of mechanical engineering companies of Vinnytsia region of Ukraine as an example. At the same time, businesses that cannot cover the cost of resources with the income from goods sale in the current year were singled out. Businesses entities positioning in the functioning environment in the context of economic security motivation (interests - increase in enterprise income, threats - growth of current and long-term liabilities, resources - use of fixed assets and employees), allowed to find opportunities to increase the efficiency of enterprises that to the greater extent are related to the manufacturing of machinery and equipment.
\end{abstract}

Keywords: Economic Security; Mechanical Engineering; Efficiency; Functioning Environment; Enterprise; Motivation

\section{Introduction}

Economic security is the core of the formation of motivational processes and sustainable development of enterprises. The importance of economic security consists of business entity profit motivation and increase of the income amount (revenue) from the product sale (goods, work, services), the need to overcome existing risks - devastation of economic activity has to be taken into consideration as well.

The very essence of the existence of enterprises involves conducting of independent economic activities that are supposed to meet social needs in goods, work and services, make profit and imply its security [1]. A number of scientists Tumin V. M., Koryakov A. G., \& Nikiforova, E. P. [11] Kozitsyn A.A., Dudinskaya M.V. [12], who have studied economic security, claim that economic security of an enterprise is its stable and most

| ${ }^{1}$ Assoc. Prof., DrS, Department of Economics, Ecology and Practical Entrepreneurship, European University, Kyiv, Ukraine

${ }^{2}$ Assoc. Prof., PhD, Department of Economics, Ecology and Practical Entrepreneurship, European University, Kyiv, Ukraine

${ }^{3}$ Assoc. Prof., DrS, Department of Marketing, Management and Public Administration Mykhailo Tuhan-

Baranovskyi Donetsk National University of Economics and Trade, Kryvyy Rih, Ukraine

${ }^{4}$ Assoc. Prof., DrS, Department of Marketing, Management and Public Administration Mykhailo Tuhan-

Baranovskyi Donetsk National University of Economics and Trade, Kryvyy Rih, Ukraine

${ }^{5}$ Assoc. Prof., PhD, Department of International Economy, National Aviation University, Kyiv, Ukraine 
efficient operation at present and high potential for successful development in the future [12].

Determination of the level of economic security of an enterprise allows to assess the real possibilities of confronting between internal and external challenges and to determine potential for further sustainable development. Cherep A., Babmindra D., Khudoliei L., Kusakova Y. applied an integral method, regression analysis and expert evaluation method in their research on the level of economic security of mechanical engineering [10].

We agree to the scientific approach to economic security based on a multifactor model and complex assessment. Kozitsyn A.A., Dudinskaya M.V. have studied the state, level and growth of economic security under the influence of external factors. The authors emphasize the need to analyze the functional components of economic security: financial, technological, intellectual, human, political, legal and environmental [12].

L. Liubokhynets, Ye. Rudnichenko, I. Dzhereliuk, O. Illiashenko, V. Kryvdyk, N. Havlovska have studied the process of minimizing the negative impact of destabilizing factors on economic security, that leads to the necessity of applying different approaches and methods that will allow companies to resist successfully and develop stably. An effective tool to minimize this negative impact is the adoption of a flexible management methodology for the organization in general and economic security in particular [12].

The core of economic security is to motivate the comprehensive development of market relations, predetermination of an effective environment. The economization of development and its integration have become one of the main patterns of the modern historical stage, under the influence of which a new global economy is formed [2]. We believe that motivation induces a company to optimize resources and achieve financial results, reflects all the possibilities of overcoming threats and compliance with interests. Scientists Desai S. [14], Mohanty AK [15], Mota A., Braga V., Ratten V. [17]., Katekhaye D., Meyer N., Magda R. [18] emphasize the need for motivation as a factor of sustainable development of enterprises. Authors Pravdiuk N., Pokynchereda V., Pravdiuk M. [16], Hong E., Lee IHI, Makino S. [19], connect economic security and sustainable development of enterprises with staff motivation first of all.

\section{The Purpose of the Research}

The purpose of the article is to investigate economic security as a factor of sustainable development of mechanical engineering on the basis of motivation assessment of economic activity in the manufacturing of machinery and equipment.

\section{Materials and Methods}

To assess the motivation of economic activity of enterprises it is necessary to measure economic security as a factor of sustainable development. O. Lyashenko approached the assessment of economic security the most reasonably. The author proposed graphical interpretations of the focused measure of economic security of an enterprise (Fig. 1-3) according to the focus, that is oriented to provide such security. In fig. 4 contains an image of a three-dimensional measure of economic security of an enterprise [1, p. 131-133]. 


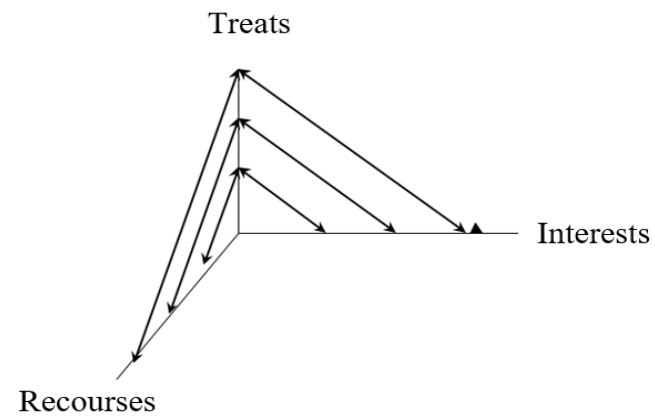

Fig. 1. Focused measure of economic security of an enterprise: focus - threats

Source: $[1, p .132]$

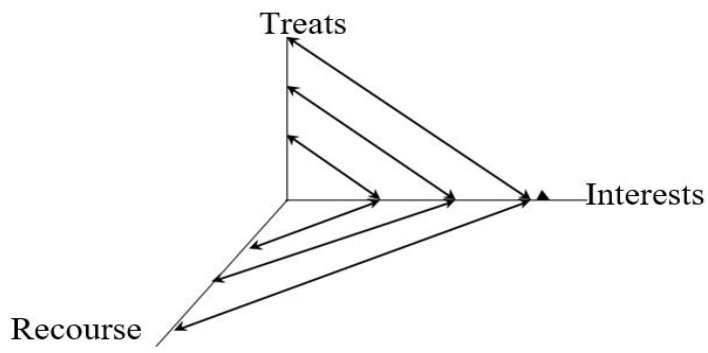

Fig. 2. Focused measure of economic security of an enterprise: focus - interests

Source: $[1, p .132]$

The core of the economic security understanding is the reconciliation of interests, the carriers of which represent both external and internal environment of an enterprise. Given that the number of interests to be agreed is quite large, and in fact, the agreement - not a one-time act, but usually a complex and long-term performance, all the above makes economic security a rather complex concept that characterizes a particular process, the effectiveness of which can be characterized in full or incompletely [1, p. 132].

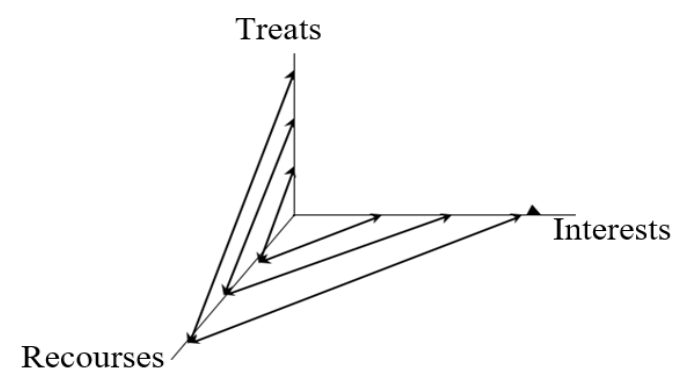

\section{Recourses}

Fig. 3. Focused measure of economic security of an enterprise: focus - resources

Source: $[1, p .133]$ 


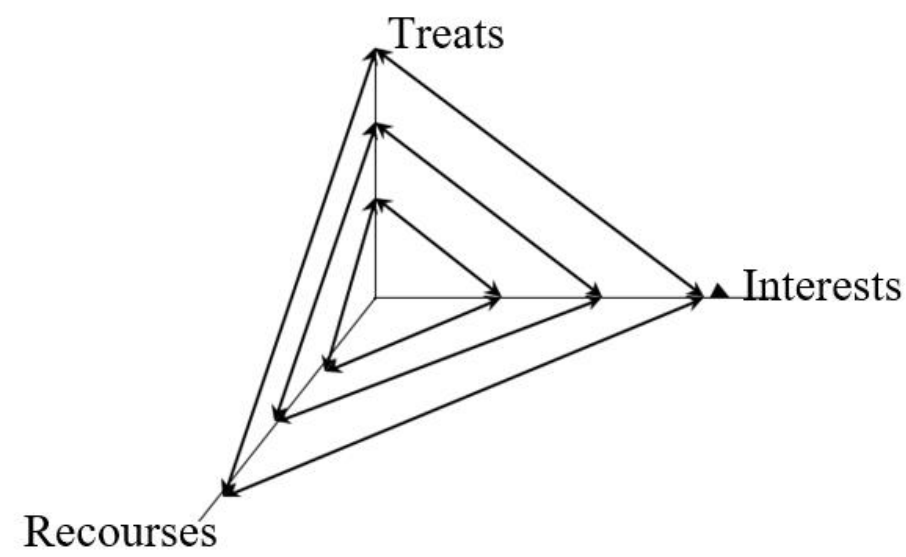

Fig. 4. The three-dimensional measure of economic security of an enterprise Source: $[1$, p. 133]

Each focused measure of economic security of an enterprise, having, of course, important focus and, at the same time, acting as a component of the three-dimensional measure of economic security of an enterprise, on the one hand, gives only a partial (corresponding to its name) idea of such a measure. On the other hand, such an idea of the focused measure of economic security of an enterprise, due to the gradual change of the focuses, somewhat simplifies its understanding, without violating the integrity of the idea of focused economic security of an enterprise [1, p. 133-134].

Thus, the analysis of approaches to establishing the degree of economic security of an enterprise showed that their nature and pattern of use are contradicting. The existence of a dilemma is dictated by the dependence of measuring the economic security of an enterprise based on the process or result. It is proposed to solve the partial elimination of the dilemma by introducing a measure of economic security of an enterprise, the understanding of which is reduced to a process-effective combination of quantitative and qualitative assessment characteristics of economic security of an enterprise. Attempts to distinguish the features of the process and the results of the measure of economic security of an enterprise through existing and / or the formation of new indexes or indicators of such features can be studied in the future; development of tools for identifying quantitative and qualitative characteristics of the assessment of partial and aggregate measures of economic security of an enterprise, etc. [1, p. 133-134].

O. Lyashenko's table is taken as a basis to assess the motivation of economic activity of mechanical engineering of agriculture by ensuring its economic security. The importance of this development lies in the justification of the three-dimensional measure of economic security of an enterprise: interests, threats, resources (Fig.5) 


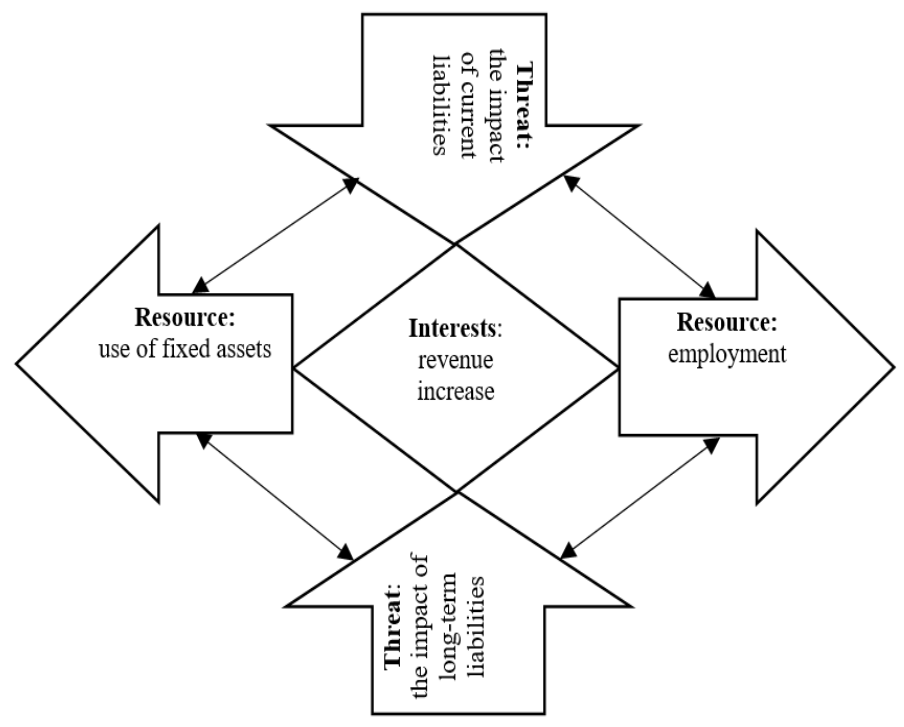

Fig. 5. Measure of economic security of enterprises of the functioning environment in mechanical engineering

\section{Results}

The interest of an enterprise forms motivation of economic activity based on the needs of an owner and social significance of the business entity. Thus, the interest of a company, on the one hand, is to increase income (revenue) from product sale (goods, work, services) and make a profit. In this case, the interest is manifested by the motivation of the company's profit, the possibility of its preservation and gradual growth.

On the other hand, the interest of an enterprise is an increase in the number of employees, an increase in labor costs, which is manifested in ensuring labor productivity. The peculiarity of business development is the advantage of the owner's motivation to invest in tangible assets (fixed assets) over the motivation to invest in wages of employees, although in terms of scientific and technological progress, the factor of human capital is more important, which stimulates a qualitatively different approach to interest of business entities in the form of socially-oriented economy. In our case, it is suggested to proceed from the interest in increasing income (revenue) from product sale (goods, work, services). The interests of an enterprise form the resources it uses - fixed assets and employees. Fixed assets are reflections of the capital of an enterprise, which creates added value. In our case, it is suggested to use depreciated cost of fixed assets, not the initial or residual value of fixed assets. This approach will allow to estimate the actual amount of the resources used in manufacturing.

Motivation is directly formed with an employee as a resource within the influence of a manager. Sometimes the management of a company and employees should be considered as a coalition, in particular G. Minzberg singled out six groups of influence: top management, employees, line managers, analysts, personnel, ideology [3]. In many cases an owner and a manager pursue different interests. A good example of it is the failure of 
the owners to attend the annual meeting of shareholders and management has complete freedom in administration and decision-making [4]. Changing the average number of employees allows to conclude about the motivation outside the profit - controlling overspending or retaining of the staff. The constant decrease in the number of employees is a sign of motivation of destruction for an enterprise. In our case another indicator is used - the cost of employees' wages, that will assess the adequacy of income (revenue) from the product sale (goods, work, services) to cover staff needs.

Threats are the danger created by the interests of an enterprise. In our case, current and long-term commitments are used as threats.

To analyze the impact of economic security on the motivation of mechanical engineering, and hence on its sustainable development, a method of analysis of the functioning environment is used, which has been proposed by M. Farrell [5] as a measure of efficiency based on the calculation of thresholds. For different cases the use of a method of analysis of the functioning environment allows to identify the potential of individual industries (engineering, agriculture) and the expediency of mortgage lending, investment, prospects of the digital economy $[6 ; 7 ; 8 ; 9]$.

As in our case the motivation of economic activity of mechanical engineering is formed on the interests, the calculation will be based on the probability of covering the income (revenue) from the product sale (goods, work, services) threats - current liabilities and costs associated with resources - covering the depreciation of fixed assets and employees labor costs.

The analysis is based on twenty enterprises of Vinnitsa region, that produce machinery and equipment for agriculture and forestry, form a conditional functioning environment. The Table 1 shows the indicators of covering current liabilities, depreciation of fixed assets and labor costs of enterprises in Vinnitsa region by the income (revenue) from product sale (goods, work, services) for each enterprise of functioning environment in 2019.

$\mathrm{EC} / \mathrm{R}$ - the ratio of covering employees' labor costs by the income (revenue) from product sale (goods, work, services);

$\mathrm{CL} / \mathrm{R}$ - the ratio of covering current liabilities of an enterprise by the income (revenue) from product sale (goods, work, services);

$\mathrm{D} / \mathrm{R}$ - the ratio of covering depreciation of fixed assets of an enterprise by the income (revenue) from product sale (goods, work, and services).

Table 1: Indicators of Covering Current Liabilities, Depreciation of Fixed Assets and Labor Costs of Mechanical Engineering in Vinnitsa Region by the Income (Revenue) From Product Sale (Goods, Work, Services) In 2019

\begin{tabular}{|c|c|c|c|c|}
\hline & Enterprises & \multicolumn{3}{|c|}{\begin{tabular}{|l|l|l|}
$E C / R$ & $C L / R$ & $D / R$ \\
\end{tabular}} \\
\hline 1 & PJSC "Khmilnyksilmash" & 19,0 & 410,72 & 193,86 \\
\hline 2 & PJSC "Dashiv Repair and Mechanical Plant" & 0,20 & 0,26 & 0,31 \\
\hline 3 & PJSC Vinnytsia Plant "Budmash" & 0,30 & 0,77 & 6,05 \\
\hline 4 & PJSC "Bar Machine-Building Plant" & 0,18 & 0,12 & 0,27 \\
\hline 5 & PJSC "Kalynivka Machine-Building Plant" & 0,19 & 1,15 & 0,13 \\
\hline 6 & PJSC "Vinnytsia Research Plant" & 0,14 & 0,31 & 0,61 \\
\hline 7 & PJSC Voronovytsia Specialized Enterprise "Agromash" & 0,32 & 7,54 & 14,45 \\
\hline 8 & PJSC "Kalynivka district enterprise "Agromash" & 0,32 & 0,56 & 0,53 \\
\hline 9 & PJSC "Bershad district enterprise" Agromash " & 0,25 & 0,53 & 5,81 \\
\hline
\end{tabular}




\begin{tabular}{|c|c|c|c|c|}
\hline № & Enterprises & \multicolumn{3}{|c|}{$E C / R C L / R D / R$} \\
\hline 10 & PJSC Vinnytsia Specialized Enterprise "Remtechsilmash" & 0,30 & 0,02 & 1,01 \\
\hline 11 & PJSC "Vinnytsiaautospecial equipment" & 0,53 & 2,37 & 1,48 \\
\hline 12 & PJSC "Yampil Instrument-Making Plant" & 0,23 & 0,19 & 0,11 \\
\hline 13 & PJSC "Mayak" & 0,17 & 0,24 & 0,08 \\
\hline 14 & PJSC "Bershad Electrotechnical Plant" & 0,33 & 0,08 & 0,89 \\
\hline 15 & PJSC "Mogyliv-Podilsky Machine-Building Plant" & 0,21 & 0,20 & 0,65 \\
\hline 16 & Vinnytsia State Experimental Prosthetic and Orthopedic Enterprise & 0,19 & 0,15 & 0,23 \\
\hline 17 & PJSC "Enterprise Medtekhnika" & 0,46 & 0,11 & 0,38 \\
\hline 18 & PJSC “Hercules" & 0,90 & 0,12 & 0,63 \\
\hline 19 & PJSC "Plasmatek" & 0,05 & 0,64 & 0,12 \\
\hline
\end{tabular}

Source: compiled and calculated by the authors.

As a result of the calculation of all the above ratios, it was defined that twelve enterprises are in the range from zero to one. It means that the economic security of these business entities allows talking about the possibility of their further motivation. Even if one of the ratios is greater than one, the economic security of that entity is at risk. For example, PJSC Vinnytsia plant "Budmash" has a ratio of covering depreciation of fixed assets by the income (revenue) from product sale (goods, work, services) equal to 6.05. At this level of depreciation of fixed assets, it is necessary to increase income (revenue) from product sale (goods, work, and services) for more than six times.

Using the elements of a method of analysis of the functioning environment, a line of technical efficiency is built according to the following parameters:

- abscissa axis: CL / R, ordinate axis: D / R (Fig. 6);

- abscissa axis: EC / R, ordinate axis: D / R (Fig. 7).

Figures 6 and 7 show the positions of enterprises whose covering ratio is between zero and one. It should be noted that only three enterprises meet these conditions of economic security (8-PJSC "Kalynivka district enterprise Agromash", 16-PJSC "Mogyliv-Podilsky Machine-Building Plant", 19-PJSC "Hercules").

The line of technical efficiency (Fig. 6) is formed by the position of six enterprises: 15 (PJSC "Bershad Electrotechnical Plant"), 18 (PJSC "Enterprise Medtekhnika"), 4 (PJSC "Barsky Machine-Building Plant"), 13 (PJSC "Yampil Instrument-Making Plant"), 14 (PJSC "Mayak"), 20 (PJSC "Plasmatek").

Technical inefficiency is a threat to the economic security of enterprises. Six companies are in danger, and therefore an important task is to motivate positions for companies in a safe area of operation. A safe zone is a zone bounded by lines 15-151-0-201-20-14-13-418. The closer to the abscissa and ordinate axes, the greater the economic security of economic entities under the given conditions of the functioning environment.

Search of safe positions is carried out with the help of two border positions of enterprises engaged in the production of machinery and equipment for agriculture and forestry - 19 and 8. The corresponding distance lines for these positions: 0-19 and 0-8. Perpendicular from the point of intersection of lines 15-18 and 0-19 on line 0-8 allows to obtain a new position for PJSC "Kalynivka district enterprise "Agromash" - 81. Similarly, in the second case - perpendicular from the point of intersection of lines 0-8 and 4-13 on line 0-19 allows to obtain a new position for PJSC "Hercules" - 191. Thus, the new position of PJSC "Mogyliv-Podilsky Machine-Building Plant" - 161 is a result of the intersection of lines 191_ 
$8^{1}$ with line $0-16$.

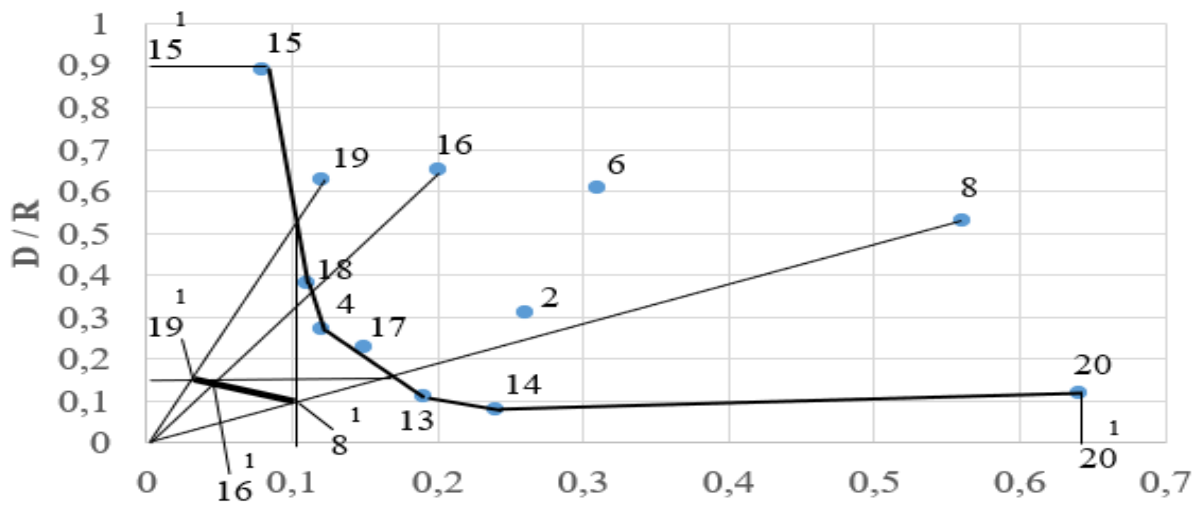

CL / R

Fig. 6. Optimization of positions of enterprises (dependence of coverage ratios of depreciation of fixed assets of enterprises by income (revenue) from sales of products (goods, work, services) on coverage current liabilities ratios of enterprises by income (revenue) from sales of products (goods, work, services))

Thus, the new positions of enterprises engaged in the production of machinery and equipment allow to ensure the economic security of economic entities by increasing the income (revenue) from sales of products (goods, work, services) or reducing current liabilities and depreciation of fixed assets by segments 19-191, 16-161, 8-81.

The line of technical efficiency (Fig. 7) is formed by the positions of three enterprises: 6 (PJSC "Vinnytsia Research Plant"), 20 (PJSC "Plasmatek"), 14 (PJSC "Mayak"). As in the previous case, among the technically efficient enterprises there is no one that produces machinery and equipment for agriculture and forestry.

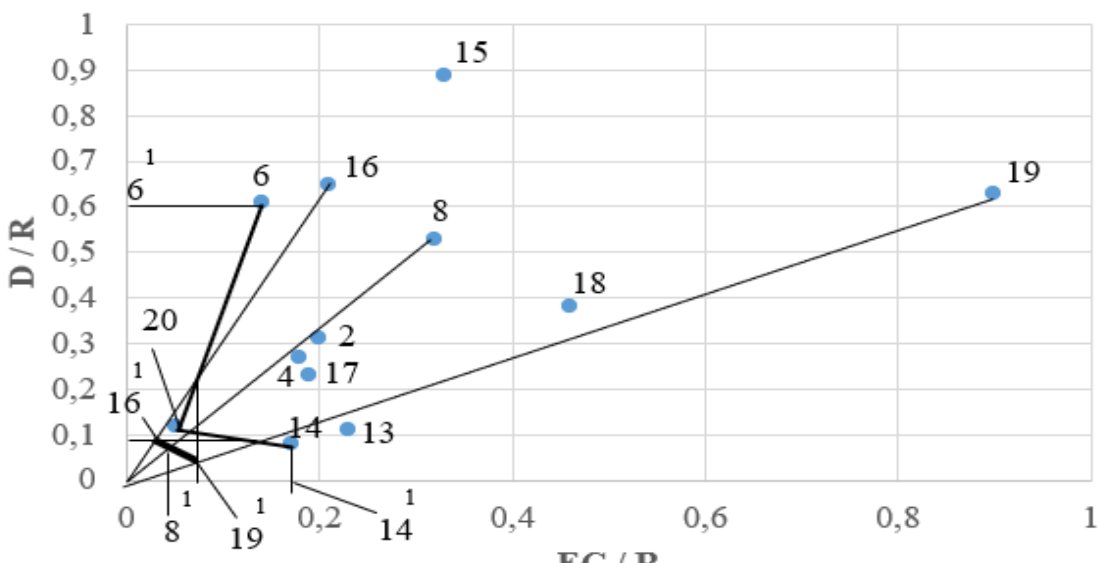

Fig. 7. Optimization of positions of enterprises (dependence of coverage ratios of depreciation of fixed assets of enterprises by income (revenue) from sales of products (goods, work, services) on coverage labor costs of employees ratios by income (revenue) from sales of products (goods, work, services)) 
The marginal positions of enterprises 16 (PJSC "Mohyliv-Podilsky Machine-Building Plant") and 19 (PJSC "Hercules"), and therefore lines 0-16 and 0-19 through these positions form intersection points, respectively, lines 6-20 and 20-14. Omitted perpendiculars allow to keep in the safety zone $61-0-141-14-20-6$ new positions of enterprises engaged in the production of machinery and equipment for agriculture and forestry - $16^{1}$ and 191 . On line $16^{1}-19^{1}$ we can find a safe position of PJSC "Kalynivka district enterprise "Agromash" (81).

Thus, the new positions of enterprises engaged in the production of machinery and equipment allow to ensure the economic security of economic entities by increasing income (revenue) from sales of products (goods, work, services) or optimizing labor costs and reducing depreciation of fixed assets on the values of segments 16-161, 8-81, 19-191.

\section{Conclusions}

The search for economically safe positions for enterprises engaged in the manufacturing of machinery and equipment was conducted based on the existing approaches to the explanation of the focused measure of economic security of an enterprise, using the method of analysis of the functioning environment. The study revealed low motivation for ensuring the economic security of the analyzed enterprises, as their income (revenue) from sales of products (goods, work, services) is insufficient to cover both current liabilities and depreciation of fixed assets, which hinders the stabilization of economic activity in the region and sustainable development of mechanical engineering.

\section{References}

Lyashenko, A. (2015). Conceptualization of economic security management of an enterprise: monograph. 2nd edition, revised and supplemented, Kiev, NISI. 348p.

Overall economic perspective to the year (2000). UNN, 1998. P. 3.

Mintzberg, H. (1983). Power In and Around Organizations - Englewood Cliffs, NJ: Prentice Hall, 700 p.

Cyert, T. \& March, H. (1989). A Behavioural Theory of the Firm, Prentice Hall, Cambridge, 1989

Farrell, M. J. (1957). The Measurement of Productive Efficiency. Journal of Royal Statistical Society, Series A, CXX, Part 3, 253-290.

Sakhno, A., Hryvkivska, O., Salkova, I. \& Kucher, L. 2019a. Evaluation of the efficiency of enterprises by the method of analysis of functioning environment. Journal of Environmental Management and Tourism, 3(35): 499-507. DOI: https://doi.org/10.14505/jemt.v10.3(35).04

Sakhno, A., Polishchuk, N., Salkova, I. \& Kucher, A. 2019b. Impact of credit and investment resources on the productivity of agricultural sector. European Journal of Sustainable Development, 8(2): 335-345. DOI:https://doi.org/10.14207/ejsd.2019.v8n2p335

Sakhno, A., Salkova, I., Broyaka, A. \& Priamukhina, N. 2020a. A methodological analysis for the impact assessment of the digitalisation of economy on agricultural growth. International Journal of Advanced Science and Technology, 8s (29): 242-249. http://sersc.org/journals/index.php/IJAST/article/view/10493

Sakhno, A., Salkova, I., Polishchuk, N., Kucher, L. \& Stashko I. 2020b. Efficiency of managing liabilities of enterprises of different types of economic activities. European Journal of Sustainable Development, 9(1): 423-431. DOI: https://doi.org/10.14207/ejsd.2020.v9n1p423

Cherep, A., Babmindra, D., Khudoliei, L. \& Kusakova, Y. (2020). Assessment of the level of financial and economic security at machine-building enterprises: Evidence from Ukraine. Problems and Perspectives in Management , 2020, vol. 18(1), Pp. 33-47, doi:10.21511/ppm.18(1).2020.04 
Tumin, V.M., Koryakov, A.G. \& Nikiforova, E.P. (2013). The main factors of socio-ecological-economic stability and development of industrial enterprises. World Applied Sciences Journal, 2013, vol. 25(6), Pp. 945-949, doi: 10.5829/idosi.wasj.2013.25.06.7066

Kozitsyn, A.A. \& Dudinskaya, M.V. (2015). Competitiveness and economic security - Priority problems of the region's metallurgical comples and its leaders in the conditions of instability. Economy of Region, 2015, vol. 3, Pp. 204-215, doi: 10.17059/2015-3-17

Liubokhynets, L., Rudnichenko, Ye., Dzhereliuk, I., Illiashenko, O., Kryvdyk, V. \& Havlovska, N. (2020). Methodological foundations of flexible management and assessing the flexibility of an enterprise economic security system. International Journal of Scientific and Technology Research, vol. 9(3), Pp. 46164621, http://www.ijstr.org/final-print/mar2020/Methodological-Foundations-Of-FlexibleManagement-And-Assessing-The-Flexibility-Of-An-Enterprise-Economic-Security-System.pdf

Desai, S. (2017). Measuring entrepreneurship: Type, motivation, and growth. IZA World of Labor, https://wol.iza.org/articles/measurement-matters-entrepreneurship-type-motivation-and-growth/long

Mohanty, K. (2018). Need System and Entrepreneurial Motivation for a Sustainable Agriventure. ICAR-Central Institute of Fisheries Technology, 2018, https://krishi.icar.gov.in/ispui/bitstream/123456789/24968 $\angle 1 / 02$ Need $\% 20$ system.pdf

Pravdiuk, N., Pokynchereda, V. \& Pravdiuk, M. (2019). The human capital of an enterprise: theory and assessment methodology, Baltic Journal of Economic Studies, vol. 5, Pp. 176-183, https://doi.org/10.30525/2256-0742/2019-5-2-176-183

Mota, A., Braga, V. \& Ratten, V. (2019). Entrepreneurship Motivation: Opportunity and Necessity. Sustainable Entrepreneurship, Springer, Cham, p. 139-165., doi: 10.14707/ajbr.180049

Katekhaye, D., Meyer, N. \& Magda, R. (2019). Entrepreneurial core motivation as a success factor for rural entrepreneurship in Western India. Polish Journal of Management Studies, 2019, vol.19, Pp. 218-230, doi: 10.17512/pjms.2019.19.2.18

Hong, E., Lee, I. H. I. \& Makino, S. (2018). Outbound foreign direct investment (FDI) motivation and domestic employment by multinational enterprises (MNEs). Journal of International Management, vol. 25(2), doi:10.1016/j.intman.2018.11.003 